Sharif University of Technology
Scientia Iranica
Transactions A: Civil Engineering
SCIENTIA
IRAN I CA

\title{
Mechanical properties of soft tailings from different depths of a Swedish tailings dam: Results from triaxial tests
}

\author{
R. Bhanbhro ${ }^{a, *}$, R. Knutsson ${ }^{\mathrm{b}}$, M. Auchar Zardari ${ }^{\mathrm{a}}$, T. Edeskär ${ }^{\mathrm{b}}$, and S. Knutsson ${ }^{\mathrm{b}}$ \\ a. Department of Civil Engineering, Quaid-e-Awam University of Engineering Science and Technology, Nawabshah, Pakistan. \\ b. Department of Civil, Environmental and Natural Resources Engineering, Luleå University of Technology, SE-97187 Luleå, \\ Sweden.
}

Received 6 June 2017; received in revised form 25 October 2017; accepted 5 May 2018

\section{KEYWORDS}

Soft tailings;

Stress-strain behavior;

Triaxial tests;

Hardening soil model;

Strength and stiffness.

\begin{abstract}
In an upstream tailings dam, loose layers might occur at different depths due to the melting of frozen layers deposited during freezing temperatures in Sweden. The reduced shear strength of such layers in a tailings dam might cause stability problems. Due to the slow consolidation process, it remains to be seen whether self-weight of a high tailings dam could affect the strength and stiffness of soft tailings located at different depths or not. For numerical modeling, appropriate strength and stiffness properties of soft tailings are required. To this end, loose layers in an upstream tailings dam were identified based on the results of cone penetration tests. Consolidated Drained (CD) triaxial tests were conducted on undisturbed soft tailings collected from different depths of the dam. The results indicated that depth did not have considerable effect on the strength and stiffness of tailings. Hardening Soil Model (HSM) at high confining pressures and axial strains underestimated the stiffness of soft tailings under CD triaxial state. This study shows that (i) proper care is required for evaluating strength and stiffness parameters for soft tailings and (ii) the application of the HSM is likely to predict more deformations, which could give an early warning before an actual failure of a tailings dam.

(C) 2020 Sharif University of Technology. All rights reserved.
\end{abstract}

\section{Introduction}

Tailings dams may be constructed using three methods such as upstream, downstream, and centerline [1]. Tailings dams raised using the upstream construction method are relatively economical as compared to those constructed with other two methods [1]. It is generally

\footnotetext{
*. Corresponding author. Tel.: 0092 3337116629

E-mail addresses: riaz@quest.edu.pk (R. Bhanbhro);

roger.knutsson@ltu.se (R. Knutsson);

muhammad.auchar@quest.edu.pk (M. Auchar Zardari); tommy.edeskar@ltu.se (T. Edeskär); sven.knutsson@ltu.se (S. Knutsson)
}

doi: $10.24200 /$ sci.2018.20418 understood that soil becomes stronger in deep layers as compared to the surface. This implies that lower layers in an embankment dam might be stronger than those at the top. This is because the strength is dependent on the confining pressure coming from the layers above. On the contrary, in an upstream tailings dam raised in freezing weather such as that in Sweden, the deposition process of tailings is carried out throughout a year. New layers of tailings are placed on old frozen layers. Due to the low permeability of tailings, the consolidation process is slow in a tailings dam. In the summer time, the melting of frozen layers may occur. Because of this, it is possible that there might be loose layers with more permeability and less shear strength. Such loose layers in a tailing dam might be sensitive 
to internal erosion, which could lead to failure. Today, it still remains to be seen what the effect of confining pressure on the strength and stiffness properties of the loose layers of tailings present at various depths of a tailings dam is.

Several studies on geotechnical properties of tailings material are reported in the literature (e.g., [215]). None of these studies has considered the effect of confining pressure on strength and stiffness properties of tailings.

To evaluate the stability of an upstream tailings dam, advanced numerical tools based on finite element methods are generally preferable to the traditional methods based on the limit equilibrium approach (see, e.g., [16-27]). At present, commercial finite element programs provide several constitutive models that cover various properties of soils in a wide range of applications in geotechnical structures. At present, due to the availability of commercial finite element software, it is possible to perform numerical modeling of tailings dams to compute realistic stability and deformations $[28,29]$. To predict reliable results of stability and deformations of a tailings dam, the selection of a proper constitutive model plays a key role. This is because tailings may show a different stress strain behavior as compared to natural materials of equivalent grains size [1]. To evaluate the suitability of a constitutive model for tailings material, reliable laboratory tests should be carried out on undisturbed samples.

The focus of the present study is to investigate mechanical behavior and the effect of confining pressure on strength and stiffness parameters of undisturbed loose tailings obtained at different depths of Aitik tailings dam located in northern Sweden. The capability of Hardening Soil Model (HSM) [30] to simulate the response of loose tailings in drained triaxial compression tests is discussed.

\section{Materials studied}

The undisturbed samples of tailings were collected from various locations of Aitik tailings dam. Void ratio and bulk density of tailings obtained from various depths are shown in Table 1. Samples were collected from those layers of the dam, which were described as loose

Table 1. Void ratio and bulk density of soft tailings sampled at various depths of Aitik tailings dam [6].

\begin{tabular}{cccc}
\hline $\begin{array}{c}\text { Dam } \\
\text { section }\end{array}$ & $\begin{array}{c}\text { Depth } \\
(\mathbf{m})\end{array}$ & $\begin{array}{c}\text { Void } \\
\text { ratio }\end{array}$ & $\begin{array}{c}\text { Bulk density } \\
\left(\mathbf{t} / \mathbf{m}^{\mathbf{3}}\right)\end{array}$ \\
\hline GH section & $7-10$ & $0.94-0.96$ & 1.73 \\
EF section & $18-20$ & $1.02-1.09$ & 1.92 \\
EF section & $21-22$ & $1.22-1.61$ & 1.85 \\
GH section & $38-47$ & $0.72-1.06$ & 1.98 \\
\hline
\end{tabular}

according to CPT results. Particle size distribution curves conducted by Bhanbhro et al. [6] showed that the tailings particles at shallow depths were more angular than those obtained from deeper depths. All samples were fully saturated with water content from 15 to $44 \%$. The average specific gravity and bulk density of the studied tailings were 2.83 and $1.73-1.98$ $\mathrm{t} / \mathrm{m}^{3}$, respectively.

All tests were subject to an axial strain rate of $5 \times 10^{-3} \mathrm{~mm} / \mathrm{min}$. The axial strains were measured indirectly by volume changes in lower chamber, and radial strains were calculated from changes in specimen's height and volume. Similarly, volumetric strains were calculated from changes in back volume of specimen by measuring the amount of water coming into or going out of specimen and initial sample dimensions. The axial deformations in the test specimen were also calibrated by external linear variable differential transducer and were assumed to be equal.

The membranes used to surround the specimen were made up of natural latex rubber. The membrane used is of $0.35 \mathrm{~mm}$ in thickness and $50 \mathrm{~mm}$ in diameter. The stiffness of the rubber membrane is about 0.38 $\mathrm{N} / \mathrm{mm}$ [31], which may affect the sample stiffness. Hence, the membrane correction was applied [31]. The corrections of -1 to $-5 \mathrm{kPa}$ were applied at axial strain rates of 4 and $20 \%$, respectively.

\section{Test procedure}

All tests in this study were conducted as Consolidated Drained (CD) triaxial tests on undisturbed samples. Before mounting the sample, all controllers and pipes attached to the apparatus were properly de-aired. The samples were put into a stretched membrane mold. The porous stone filters were provided to allow drainage from both ends. After providing porous stone filters, the bottom end of the sample was fixed with a triaxial cell by unfolding membrane on the bottom part of the triaxial cell. O-rings were applied and mold was then taken out. The sample was then surrounded by a split mold to install top cap. This was done because of the sensitivity of material and to avoid any disturbance during the installation of the sample. The process of mounting is shown in Figure 1. The triaxial cell was filled with de-aired water by opening the top cap and allowing water to enter and de-air the cell. Once the cell was filled in with water, the top outlet was closed, assuring that there was no air entrapped in the cell and pipes. The bottom drainage outlet was connected to the back-pressure controller to saturate the material. The saturation process was done at a pressure difference of $5-10 \mathrm{kPa}$ for coarser specimens only.

This was the only process where drainage line at the top end was kept open. In the rest of the 


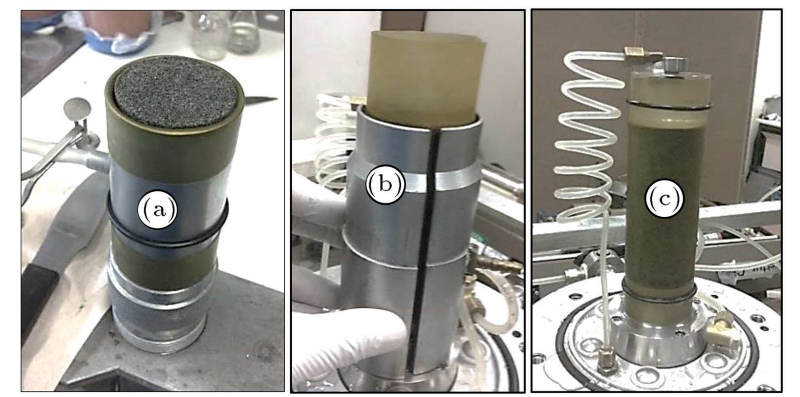

Figure 1. Sample taken out from sampler and mounted on triaxial cell: (a) Membrane stretcher, (b) split mold, and (c) sample after mounting.

process, the back-pressure controller was connected to the top outlet of the specimen for applying back pressure, and the bottom outlet was connected to the pore-pressure recorder. Pre-consolidation was carried out by increasing the radial stresses up to $20 \mathrm{kPa}$ and back-pressure to $10 \mathrm{kPa}$; then, the effective stresses were kept in the range of $10 \mathrm{kPa}$.

\subsection{Saturation}

Saturation of the specimen was conducted by increasing the backpressure and cell pressure simultaneously with a linear rate by keeping the effective stresses at $10-15 \mathrm{kPa}$. The backpressure of $210-220 \mathrm{kPa}$ was used in all of the tests. The rate of the application of backpressure and cell pressure was kept at 1.2-1.8 $\mathrm{kPa} / \mathrm{min}$ for all the tests. To ensure the required saturation of the specimen, a B-check was performed. This was done by increasing the cell pressure by 50 $\mathrm{kPa}$ and measuring the change in pore pressure. The $B$-value [31] can be calculated as follows:

$$
B=\frac{\Delta u}{\Delta \sigma_{3}}
$$

where $\Delta u$ is the change in pore pressure, and $\Delta \sigma_{3}$ is the change in cell pressure. Typical $B$-values calculated in this study were in the range of $0.95-0.98$; only two tests showed $B$-value as 0.89 . The specimen with $B$ values of 0.9 to 1 can be considered as fully saturated [31].

\subsection{Consolidation}

After the $B$-check, if the sample was considered saturated, the backpressure for all the tests would be kept at $250-300 \mathrm{kPa}$. The radial stresses were then increased to achieve the required effective stresses for the test being carried out. If the required effective stresses were more than $100 \mathrm{kPa}$, the radial stresses would be applied in steps with each step of $100 \mathrm{kPa}$. Back volume changes were monitored in each step with a condition that no change in volume should occur for five minutes to proceed to the next step.

\subsection{Axial strain}

Once the effective stresses were set to desired values and no volume changes were observed for five minutes, axial strains were applied with a constant rate of $5 \times 10^{-3} \mathrm{~mm} / \mathrm{min}$. The tests, which were performed at a confining stress of $100 \mathrm{kPa}$, were subjected to loading, unloading, and reloading. The initial loading was applied based on the assumption (based on assumed strength parameters) of $75 \%$ of maximum deviator stress followed by unloading. Reloading was then applied once the specimen was unloaded back to deviator stress equivalent to zero. Axial strains in unloading and reloading were kept at the same rate as those in the primary loading. The loading, unloading, and reloading were conducted to determine the parameters of HSM. All of the tests performed were subjected to axial strains of $20 \%$ except that which was subjected to $10 \%$, since it was terminated due to the limit exceeded in the pressure-volume controller.

\section{Results and discussions}

\subsection{Stress-strain behavior of soft tailings}

CD triaxial compression tests were conducted for all of the samples taken from various depths (cf. Table 1). The deviatoric stress versus axial strain and volumetric strain for the tests conducted at confining pressures of $50,100,250$ and $400 \mathrm{kPa}$ are presented in Figure 2. Of note, for all of the samples taken from different depths,

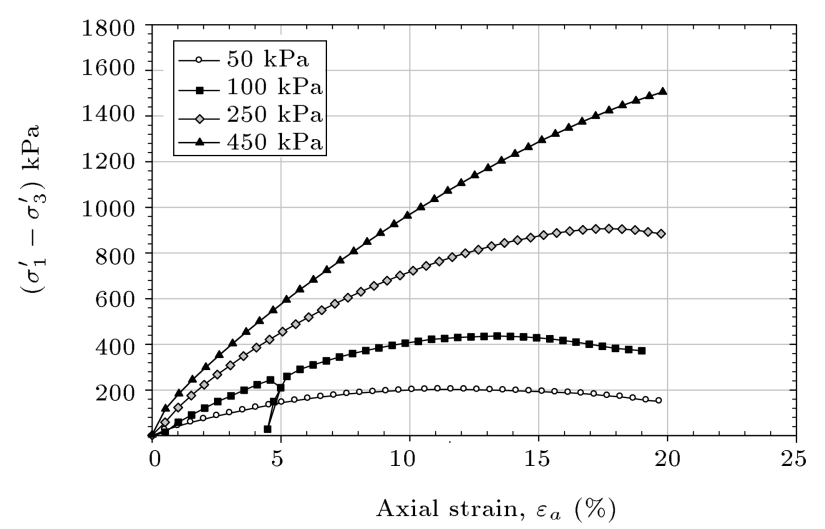

(a)

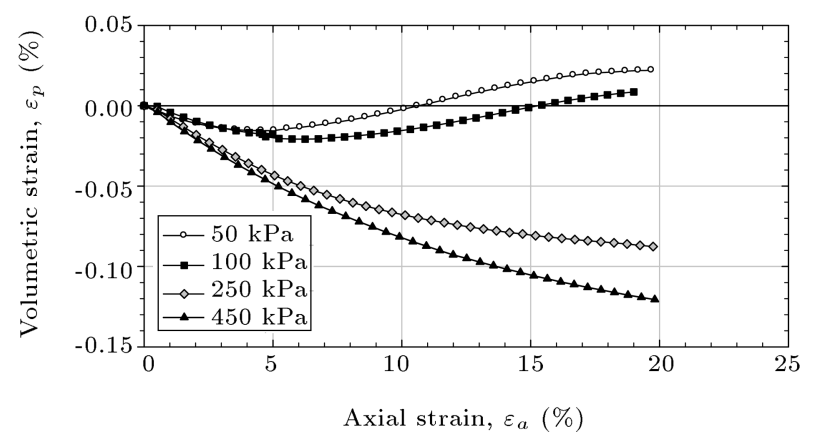

(b)

Figure 2. Stress strain response of soft tailings in consolidated drained triaxial test. Deviator stress (a) and volumetric strains (b) versus axial strains. 
the stress strain behavior was almost the same. With an increase in confining pressures, the axial strains at which failure occurred increased; this was observed in all of the tests. This is consistent with common observations such that the tests performed at higher confining stresses show failure at larger strains. The figure also shows volumetric strains plotted versus axial strains. The dilatant and contractant behaviors were observed for the tests that were performed at low confining and high confining pressures, respectively.

\subsection{Effective principal stress ratios}

The effective principal stress ratio versus axial strain curves for CD triaxial compression tests conducted on tailings sampled at different depths are plotted in Figure 3. It can be observed that almost the same effective principal stress ratios at failure were obtained for soft tailings irrespective of the depth where samples were collected. This implies that the stress strain behavior of these soft tailings is independent of the depth.

Higher effective principal stress ratios were observed for all of the tests conducted at low confining stresses as compared to high confining pressure. High

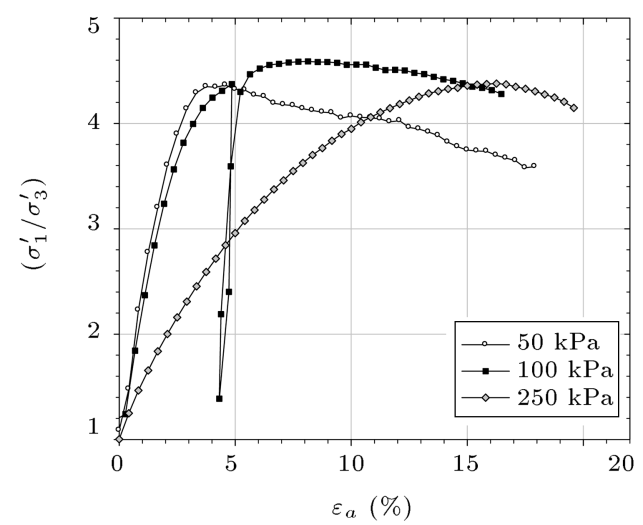

(a)

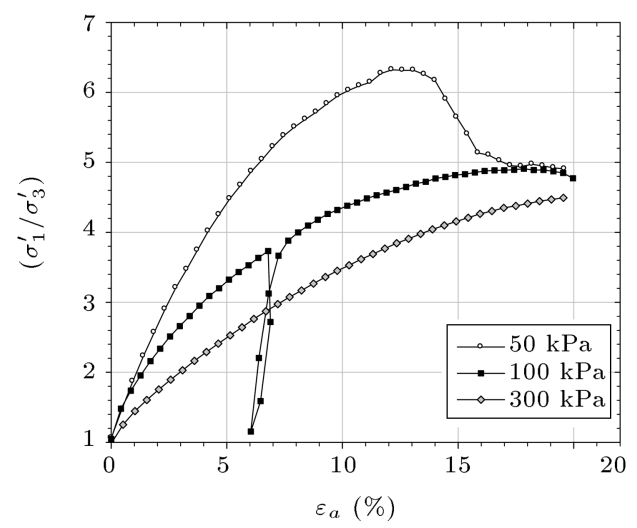

(c) principal stress ratios were observed for the specimen with a high value of the void ratio (i.e., 1.6) at low confining stresses (Figure 3(c)). There was no visible peak identified until $10 \%$ of axial strains in most of the tests conducted except those which were conducted at lower confining pressures and with void ratios of 0.9 . The specimens collected from the shallow depth (i.e., $7-10 \mathrm{~m}$ ) of the dam with a void ratio of 0.9 showed a peak stress ratio near $5 \%$ of axial strains (Figure 3(a)). In general, the lower effective principal stress ratios were observed for specimens that were tested at high confining pressures; this trend is in agreement with the studies reported in the literature (e.g., [4]).

\subsection{Strength parameters}

The values of the effective friction angle of tailings collected at different depths in the dam are presented in Table 2. The values were found to be in the range of 39.1 to 41.1 degrees. These values are in agreement with a previous study reported Jantzer [32]. No considerable influence of the depth was observed on values of effective friction angle of the tailings despite the fact that the specimens at shallow depth were more angular than those located deeper.

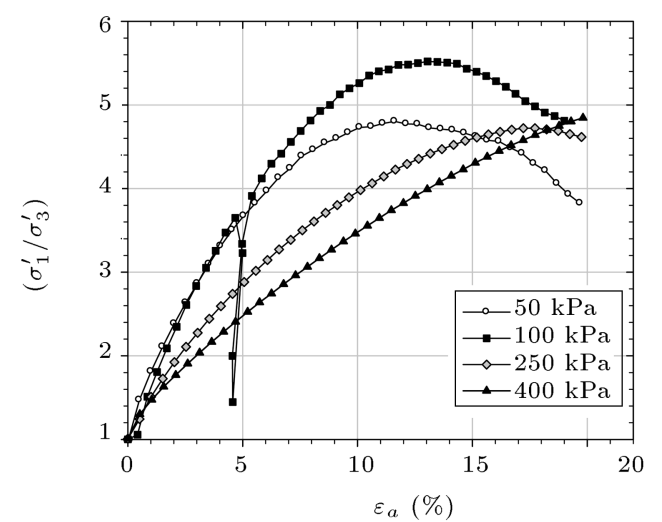

(b)

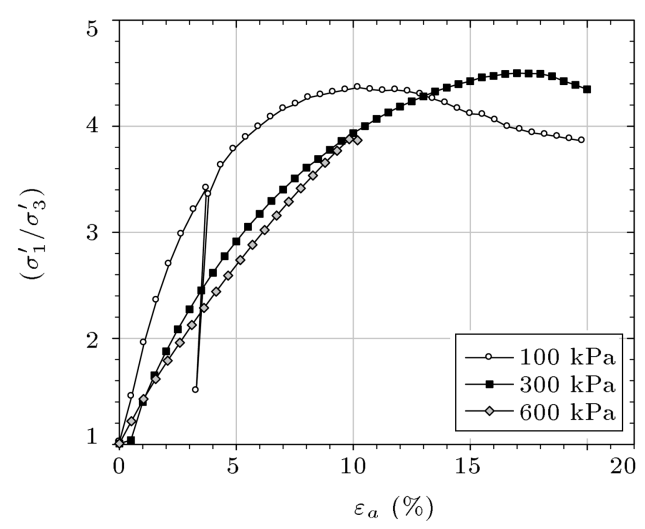

(d)

Figure 3. Principal effective stress ratios versus axial strains: (a) GH section at 7-10 m depth, (b) EF section at 18-20 m depth, (c) EF section at 21-22 m depth, and (d) GH section at 38-47 m depth. 
Table 2. Variation of effective friction angle of tailings with respect to depth.

\begin{tabular}{ccc}
\hline $\begin{array}{c}\text { Sample } \\
\text { location }\end{array}$ & $\begin{array}{c}\text { Depth from } \\
\text { surface of dam } \mathbf{( m )}\end{array}$ & $\begin{array}{c}\text { Friction } \\
\text { angle (deg) }\end{array}$ \\
\hline GH section & $7-10$ & 39.1 \\
EF section & $18-20$ & 41.1 \\
EF section & $21-22$ & 40.2 \\
GH section & $38-47$ & 39.7 \\
\hline
\end{tabular}

\subsection{Effective stress paths}

Figure 4(a) presents the effective stress paths for CD triaxial tests on tailings material subjected to different confining pressures (EF section,18-20 m depth). The figure also shows the best curve fit for the critical state line passing through the origin. The slope of the critical state line (here written as $M$ ) was found to be in the range of 1.61 to 1.73 . One set of results from GH section at $7-10 \mathrm{~m}$ depth showed a certain cohesion intercept (here written as $k$ ) on the $q$-plane when $p^{\prime}$ was zero. When $p^{\prime}=0$, the deviator stress observed was $q=k$; this may not hold in the case of granular soils. The critical state line slope in this case was observed as $M_{k}=1.55$, which was then plotted as the best fit curve that passed through the origin and showed the value as $M=1.63$, as presented in Figure 4(b).

\subsection{HSM parameters}

The HSM is capable of simulating the stress strain response of soft and hard soils subjected to the static loading condition in various geotechnical applications [30]. The HSM captures the associated decrease and increase of the mean effective stress exhibited by soft and hard soils, respectively. Deformations and failure of soils could be predicted reliably using the HSM [30].

The HSM simulates hyperbolic stress-strain relationship in a more realistic way than Mohr-Coulomb model does [30]. For drained triaxial loading, the relation between axial strain and deviator stress can be defined as a hyperbolic function and is described as follows [29]:

$$
\varepsilon_{1}=\frac{q_{a}}{2 E_{50}}-\frac{q}{q_{a}-q} \quad \text { for } \quad q<q_{f},
$$

where $\varepsilon_{1}$ is the strain, $q$ is the deviatoric stress, and $q_{f}$ is the ultimate deviatoric stress described with MohrCoulomb failure criterion, $q_{f}=\frac{6 \sin \phi^{\prime}}{3-\sin \phi^{\prime}}\left(\sigma_{3}^{\prime}+c^{\prime} \cot \phi^{\prime}\right)$, and $q_{a}$ is the asymptote of hyperbola.

$$
q_{a}=\frac{q_{f}}{R_{f}}
$$

where $R_{f}$ is the failure rate relationship between failure stresses $q_{f}$ and $q_{a}$, and $q_{f}=q_{a}$ when $R_{f}=1$.

The evaluation procedure of parameters of the HSM [33] is described in Table 3. The parameters of HSM were evaluated based on the drained triaxial tests, and standard oedometer tests were conducted on tailings material. The unloading and reloading responses of a CD triaxial test at a confining stress of $100 \mathrm{kPa}$ are shown in Figure 5 .

The HSM can capture hyperbolic stress strain behavior exhibited by drained triaxial compression tests on soil (Figure 6). The stress-strain relationship in the unloading-reloading state is controlled by $E_{u r}$

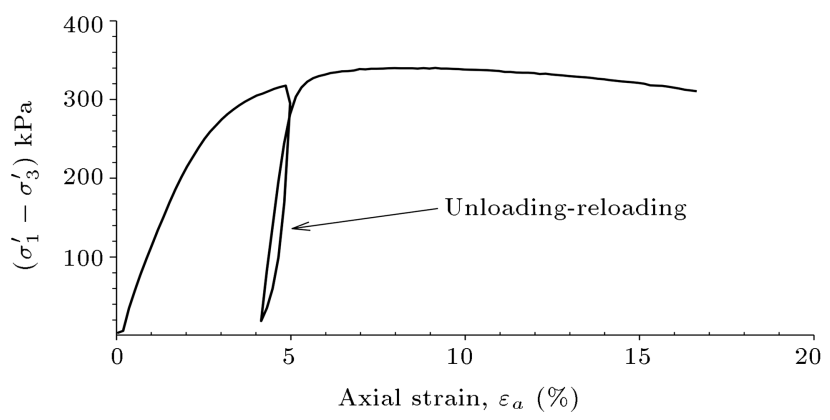

Figure 5. Loading, unloading, and reloading behaviors of a consolidated drained triaxial compression test performed on soft tailings at a confining pressure of $100 \mathrm{kPa}$.

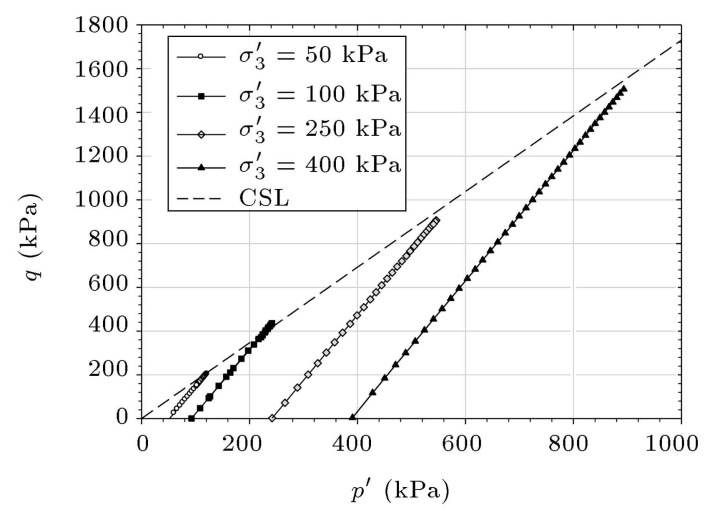

(a)

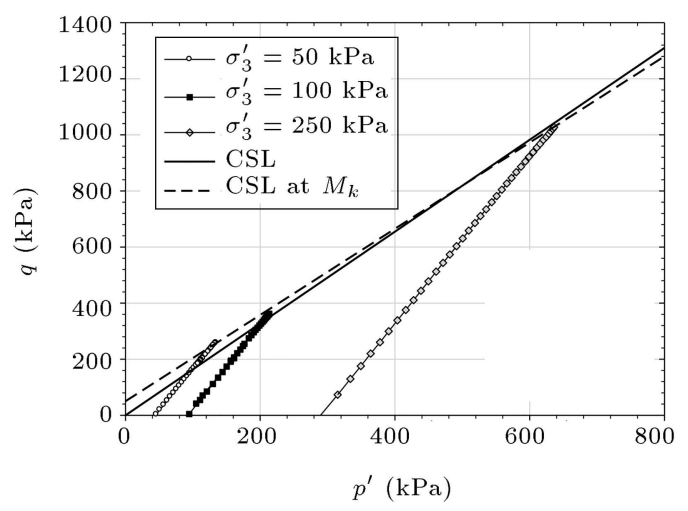

(b)

Figure 4. The effective stress paths for CD triaxial tests on tailings samples taken from (a) EF section at 18-20 m depth and (b) GH section at $7-10 \mathrm{~m}$ depth. 
Table 3. Evaluation procedure of parameters of hardening soil model [33].

\begin{tabular}{|c|c|c|}
\hline $\begin{array}{c}\text { Parameter } \\
\text { symbol }\end{array}$ & Description & Parameter evaluation \\
\hline$\phi^{\prime}$ & Internal friction angle & Slope of failure line from MC failure criterion \\
\hline$c^{\prime}$ & Cohesion & $y$-intercept of failure line from MC failure criterion \\
\hline$R f$ & Failure ratio & $\left(\sigma_{1}-\sigma_{3}\right)\left(\sigma_{1}-\sigma_{3}\right)_{u l t}$ \\
\hline$\psi$ & Dilatancy angle & Function of $\varepsilon_{a}$ and $\varepsilon_{\nu}$ \\
\hline \multirow{2}{*}{$E_{50}^{r e f}$} & Reference secant stiffness & $y$-intercept in \\
\hline & from drained triaxial test & $\log \left(\sigma_{3} / p^{r e f}\right)-\log \left(E_{50}\right)$ space \\
\hline \multirow{2}{*}{$E_{\text {oed }}^{r e f}$} & Reference tangent stiffness & $y$-intercept in \\
\hline & for oedometer primary loading & $\log \left(\sigma_{1} / p^{\text {ref }}\right)-\log \left(E_{\text {oed }}\right)$ space \\
\hline$E_{u r}^{r e f}$ & Reference unloading/reloading stiffness & $y$-intercept in $\log \left(\sigma_{3} / p^{r e f}\right)-\log \left(E_{u r}\right)$ space \\
\hline$m$ & Exponential power & Slope of trend-line in $\log \left(\sigma_{3} / p^{r e f}\right)-\log \left(E_{50}\right)$ space \\
\hline$\nu_{u r}$ & Unloading/reloading Poisson's ratio & 0.15 to 0.3 \\
\hline$K_{0}^{n c}$ & Coefficient of earth pressure at rest (NC state) & $1-\sin \phi^{\prime}($ default setting) \\
\hline
\end{tabular}

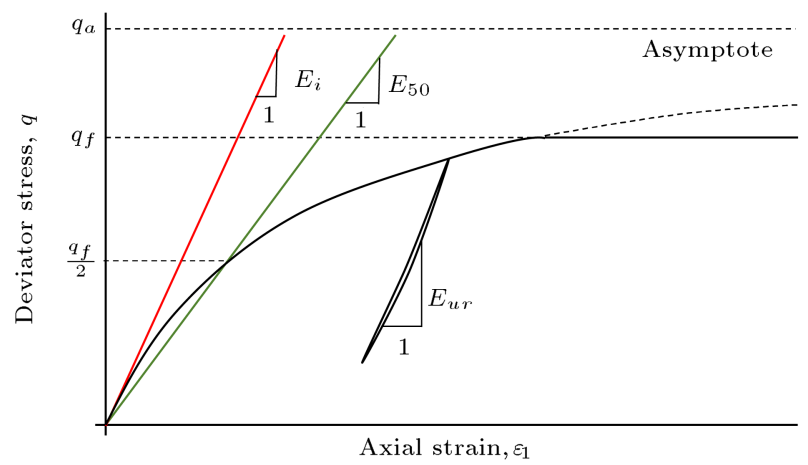

Figure 6. Hyperbolic stress strain behavior in drained triaxial test.

(Young's modulus for unloading and reloading) and $\nu_{u r}$ (Poisson's ratio for unloading and reloading). Another feature of the HSM is the stress-dependent modulus corresponding to reference confining stress $\left(p^{r e f}\right)$, and the amount of stress dependency is given by power ' $m$ '. The values of $m$ values of silts/sands and soft clays may be taken as 0.5 and 1 , respectively [34]. The stiffness modulus is stress dependent by power $m$ [30] and can be written in the following generalized form [29]:

$$
E_{50}=E_{50}^{r e f}\left(\frac{c^{\prime} \cos \phi^{\prime}-A \sin \phi^{\prime}}{c^{\prime} \cos \phi^{\prime}+p^{r e f} \sin \phi^{\prime}}\right)^{m} .
$$

For $E_{50}$ and $E_{u r}: A=\sigma_{3}^{\prime}$ for $E_{\text {oed }}: A=\sigma_{1}^{\prime}$.

\subsection{HSM calibration}

SoilTest tool in PLAXIS 2D [34] was used to calibrate the parameters for the HSM from the conducted laboratory tests. The simulations were performed on CD triaxial and oedometer tests.

Initially, the HSM parameters were obtained from the results of the oedometer test and CD triaxial test at a confining pressure of $100 \mathrm{kPa}$. Slight modifications were then made to the model parameters to find the best match between simulated behavior and laboratory tests. The evaluated HSM parameters are presented in Table 4.

Figure 7 shows the behavior of the oedometer test and simulated behavior using the HSM. Initially, it was observed that the simulated vertical strains in the oedometer test were low as compared to laboratory observations. When the oedometer modulus decreased, the best curve fit was achieved (see Figure 7). However, the application of the decreased oedometer modulus caused a slight increase in volumetric strains in simulated triaxial tests.

The deviatoric stress versus the axial strain response simulated with the HSM is compared with CD triaxial tests performed on soft tailings (Figure 8). It can be observed that the deviatoric stresses simulated with the HSM were slightly higher at low axial strains, whereas, at higher axial strains, the simulated devia-

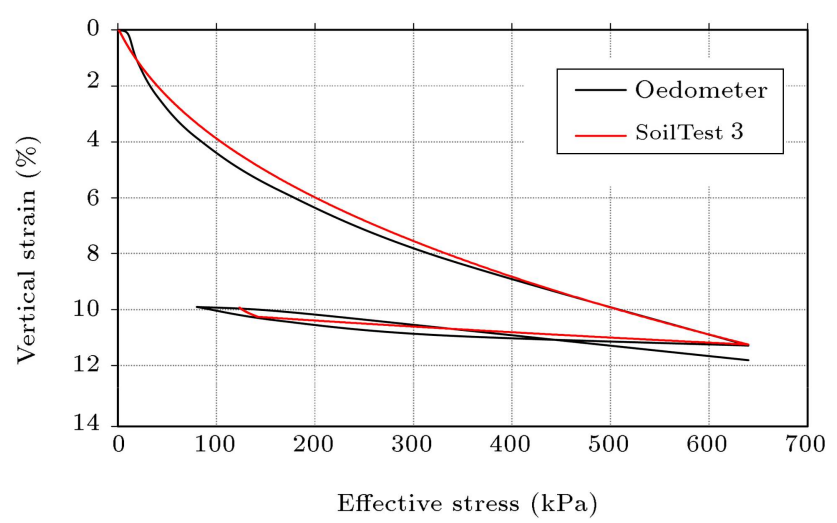

Figure 7. Comparison of loading and unloading responses of the oedometer test with Hardening Soil Model (HSM) simulations. 
Table 4. Hardening soil model parameters for soft tailings located at various depths of Aitik tailings dam [29].

\begin{tabular}{|c|c|c|c|c|}
\hline \multirow[b]{2}{*}{ Parameter } & \multicolumn{3}{|c|}{ Material location } & \multirow[b]{2}{*}{$\begin{array}{c}\text { GH } \\
(38-47 \mathrm{~m}) \\
\end{array}$} \\
\hline & $\begin{array}{c}\text { GH } \\
(7-10 \mathrm{~m}) \\
\end{array}$ & $\begin{array}{c}\text { EF } \\
(18-20 \mathrm{~m}) \\
\end{array}$ & $\begin{array}{c}\text { EF } \\
(12-22 \mathrm{~m}) \\
\end{array}$ & \\
\hline$E_{50}^{r e f}(\mathrm{kPa})$ & 6900 & 6032 & 5500 & 8254 \\
\hline$E_{\text {oed }}^{r e f}(\mathrm{kPa})$ & 4000 & 3500 & 3950 & 6000 \\
\hline$E_{u r}^{r e f}(\mathrm{kPa})$ & 20000 & 32600 & 22000 & 40000 \\
\hline$m$ & 0.7 & 0.6 & 0.57 & 0.5 \\
\hline$P^{r e f}(\mathrm{kPa})$ & 100 & 100 & 100 & 100 \\
\hline$\nu_{u r}$ & 0.3 & 0.15 & 0.15 & 0.15 \\
\hline$c^{\prime}(\mathrm{kPa})$ & 0 & 7.5 & 0 & 0 \\
\hline$\phi^{\prime}(\mathrm{deg})$ & 39.5 & 40.2 & 40 & 38.66 \\
\hline$\psi(\operatorname{deg})$ & 2 & 2.5 & 2.5 & 1 \\
\hline$R_{f}\left(\mathrm{kN} / \mathrm{m}^{3}\right)$ & 0.8 & 0.9 & 0.9 & 0.9 \\
\hline$\gamma_{\text {unsat }}\left(\mathrm{kN} / \mathrm{m}^{3}\right)$ & 14.9 & 16.2 & 15.7 & 14.3 \\
\hline$\gamma_{\text {sat }}\left(\mathrm{kN} / \mathrm{m}^{3}\right)$ & 19.5 & 20.5 & 20.1 & 19.3 \\
\hline
\end{tabular}

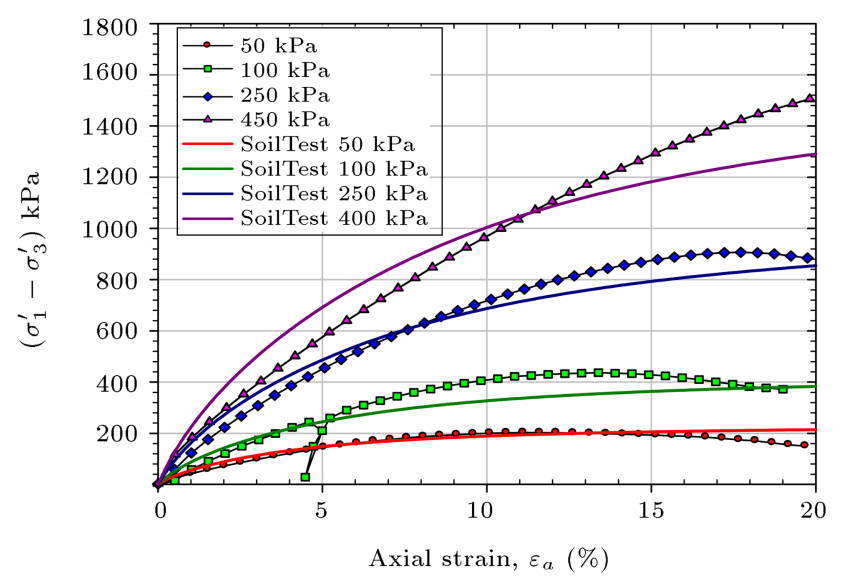

Figure 8. Stress strain behavior of consolidated drained triaxial test on soft tailings material compared with hardening soil model simulation.

toric stresses were lower than that of laboratory tests. Figure 9 shows the comparison of effective stress paths simulated with the HSM and obtained from CD triaxial tests. It can be observed that both types of effective stress paths are similar. On the other hand, the HSM slightly overestimated volumetric behavior of the soft tailings, compared to that of CD triaxial tests.

\section{Discussion}

The peak deviatoric stress was observed at high strains for the tests performed at high confining pressures of 250 and $400 \mathrm{kPa}$. However, the tests performed at lower confining pressures showed peak stress followed by softening behavior. When particles have higher strength than the confining pressure, the tailings may have greater stiffness due to the interlocking of particles [35]. During the application of axial loads, the stiffness of particles increased to the peak value. Post-

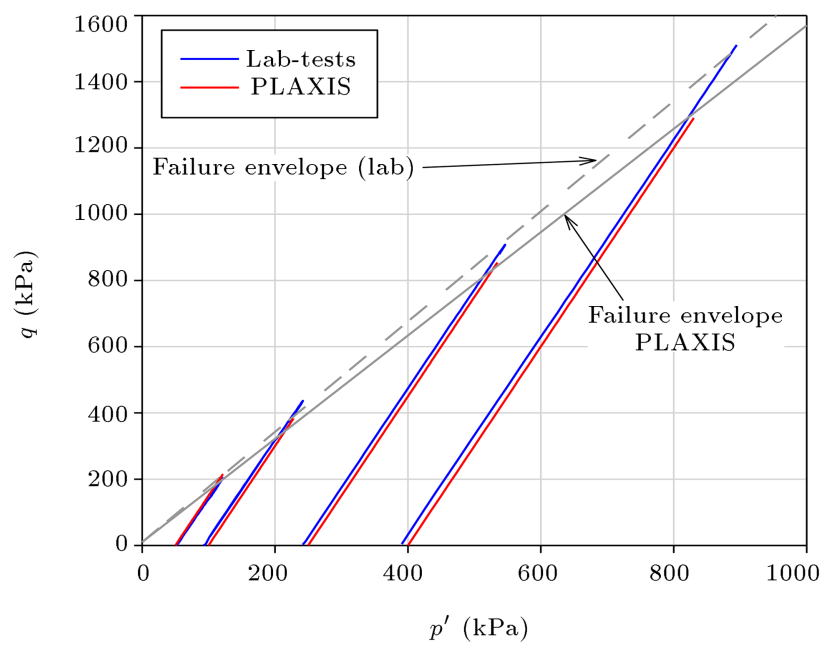

Figure 9. Comparison of effective stress path simulated using hardening soil model with that of consolidated drained triaxial test results.

peak behavior of tailings shows crushing or sliding of particles. Consequently, the stiffness of tailings was reduced [33].

The HSM slightly overestimated stiffness at small strains and underestimated stiffness at larger strains (Figure 9). However, the underestimated values of stiffness could predict exaggerated deformations, which might give an early warning before the occurrence of true failure of a tailing dam.

\section{Concluding remarks}

In this study, the effect of confining pressure of increased height of an upstream tailings dam was investigated on soft tailings located in deeper layers. In addition, the capability of Hardening Soil Model (HSM) was evaluated to simulate stress strain and 
volumetric responses of soft tailings. The following conclusions can be made:

- No considerable influence of self-weight of the dam was observed on strength and stiffness properties of soft tailings located at different depths;

- At high confining pressure and axial strains, as would be expected during future raisings of the dam, the HSM overestimated the stiffness of undisturbed soft tailings, obtained at different depths, as compared to the results of CD triaxial tests;

- Numerical analysis of a tailings dam using the HSM may predict slightly more deformations in those zones, where soft tailings are located;

- A future study is suggested to evaluate the suitability of the HSM to simulate the consolidated undrained response of soft tailings.

\section{Acknowledgments}

Luleå University of Technology is to be acknowledged for financial support and providing laboratory resources. TCS AB and Boliden AB are acknowledged for providing background information and material for the tests and for valuable participation during the interpretation of the results. The financial support from J. Gust. Richert Foundation is also highly acknowledged. The research presented was carried out as a part of "Swedish Hydropower Centre - SVC". SVC has been established by the Swedish Energy Agency, Elforsk and Svenska Kraftnät together with Luleå University of Technology, The Royal Institute of Technology, Chalmers University of Technology, and Uppsala University.

\section{References}

1. Vick, S., Planning, Design, and Analysis of Tailings Dams, BiTech Publishers, Vancouver (1990).

2. Owolagba, J. and Azam, S. "Geotechnical properties of centrifuged oil sand fine tailings", Envir. Geotech., 2(5), pp. 309-316 (2014).

3. Lee, J.K. and Shang, J.Q. "Evolution of thermal and mechanical properties of mine tailings and fly ash mixtures during curing period", Can. Geotech. J., 51(5), pp. 570-582 (2014).

4. Bhanbhro, R., Knutsson, R., Edeskär, T., and Knutsson, S. "Mechanical properties of soft tailings from a Swedish tailings impoundment: Results from direct shear tests", Elec. J. of Geotech. Eng., 19(Z), pp. 9023-9039 (2014).

5. Jia, Y., Stenman, D., Mäkitalo, M., Maurice, C., and Öhlander, B. "Use of amended tailings as mine waste cover", Waste Biomass Valori, 4(4), pp. 709718 (2013).
6. Bhanbhro, R., Knutsson, R., Rodriguez, J., Edeskär, T., and Knutsson, S. "Basic description of tailings from Aitik focusing on mechanical behaviour", Int. J. Emerg. Tech. Adv. Eng., 3(12), pp. 65-69 (2013).

7. Rodriguez, J.M. and Edeskär, T. "Case of study on particle shape and friction angle on tailings", J. Adv. Sci. Eng. Res., 3(4), pp. 373-387 (2013).

8. Dimitrova, R.S. and Yanful, E.K. "Factors affecting the shear strength of mine tailings/clay mixtures with varying clay content and clay mineralogy", Eng. Geol., 125, pp. 11-25 (2012). doi.org/10.1016/j.enggeo.2011.10.013.

9. Liu, H.M., Yang, C.H., Zhang, C., and Mao, H.J. "Study on static and dynamic strength characteristics of tailings silty sand and its engineering application", Saf. Sci., 50(4), pp. 828-834 (2012).

10. Dimitrova, R.S. and Yanful, E.K. "Undrained strength of deposited mine tailings beds: effect of water content, effective stress and time of consolidation", Geotech. Geol. Eng., 29(5), pp. 935-951 (2011).

11. Villavicencio, A.G., Breul, P., Bacconnet, C., Boissier, D., and Espinace, A.R. "Estimation of the variability of tailings dams properties in order to perform probabilistic assessment", Geotech. Geol. Eng, 29, pp. 10731084 (2011).

12. Wickland, B.E., Wilson, G.W., and Wijewickreme, D. "Hydraulic conductivity and consolidation response of mixtures of mine waste rock and tailings", Can. Geotech. J., 47(4), pp. 472-485 (2010).

13. Shamsai, A., Pak, A., Bateni, S.M., and Ayatollahi, S.A.H. "Geotechnical characteristics of copper mine tailings: a case study", Geotech. Geol. Eng., 25(5), pp. 591-602 (2007).

14. Guo, P. and Su, X. "Shear strength, interparticle locking, and dilatancy of granular materials", Can. Geotech. J., 44(5), pp. 579-91 (2007).

15. Qiu, Y. and Sego, D. "Laboratory properties of mine tailings", Can. Geotech. J., 38(1), pp. 183-90 (2001).

16. Zardari, M.A., Mattsson, H., Knutsson, S., and Ormann, L. "Comparison of three dimensional and two dimensional axisymmetric finite element analyses of a corner section of a tailings dam", Sci. Iran., 24(5), pp. 2320-2331 (2017).

17. Ormann, L., Zardari, M.A., Mattsson, H., Bjelkevik, A., and Knutsson, S. "Numerical analysis of strengthening by rockfill embankments on an upstream tailingsdam", Can. Geotech. J., 50(4), pp. 391-399 (2013). doi: $10.1139 / \mathrm{cgj}-2012-0255$

18. Yu, S.Y., Shao, L.T., and Liu, S.Y. "Stability analysis of tailings dam based on finite element limit equilibrium method", Rock. Soil. Mech., 34(4), pp. 1185-1190 (2013). 
19. Rout, S., Sahoo, T., and Das, S. "Design of tailing dam using red mud", Open. Eng., 3(2), pp. 316-328 (2013).

20. Ozcan, N.T., Ulusay, R., and Isik, N.S. "A study on geotechnical characterization and stability of downstream slope of a tailings dam to improve its storage capacity (Turkey)", Environ. Earth Sci., 69(6), pp. 1871-1890 (2013).

21. Özer, A.T. and Bromwell, L.G. "Stability assessment of an earth dam on silt/clay tailings foundation: A case study", Eng. Geol., 151, pp. 89-99 (2012).

22. Ormann, L., Zardari, M.A., Mattsson, H., Bjelkevik, A., and Knutsson, S. "Numerical analysis of curved embankment of an upstream tailing dam", Elec. J. of Geotech. Eng., 16/I, pp. 931-944 (2011).

23. Pak, A. and Nabipour, M. "Numerical study of the effects of drainage systems on saturated/unsaturated seepage and stability of tailings dams", Mine. Water. Environ., 36(3), pp. 341-355 (2017).

24. Saad, B. and Mitri, H. "Hydromechanical analysis of upstream tailings disposal facilities", J. of Geotech. and Geoenviron. Eng., 137(1), pp. 27-42 (2011).

25. Psarropoulos, P.N. and Tsompanakis, Y. "Stability of tailings dams under static and seismic loading", Can. Geotech. J., 45(5), pp. 663-675 (2008).

26. Pirulli, M., Barbero, M., Marchelli, M., and Scavia, C. "The failure of the Stava Valley tailings dams (northern Italy): numerical analysis of the flow dynamics and rheological properties", Geoenviron., Disas., 4(3), pp. 1-15 (2017).

27. Pastor, M., Quecedo, M., Fernández Merodo, J.A., Herrores, M.I., Gonzalez, E., and Mira, P. "Modelling tailings dams and mine waste dumps failures", Geotechnique, 52(8), pp. 579-591 (2002).

28. Hassellund, L., Knutsson, R., Mattsson, H., and Knutsson, S. "Numerical simulations of stability of a gradually raised upstream tailings dam in northern sweden", Elec. J. of Geotech. Eng., 21(13), pp. 46994720 (2016).

29. Knutsson, R. "Tailings dam performance: Modeling and safety analysis of a tailings dam", Licentiate of Engineering Thesis, Lulea University of Technology, Lulea, Sweden (2015).

30. Schanz, T., Vermeer, P., and Bonnier, P. "The hardening soil model: formulation and verification", Beyond 2000 in Computational Geotechnics-10 Years of PLAXIS, Balkema, Rotterdam, pp. 281-296 (1999).

31. Head, K.H., Manual of Soil Laboratory Testing, Effective Stress Tests, 3, Whittles Publishing (2014).

32. Jantzer, I. "Critical hydraulic gradients in tailings dams: comparison to natural analogies", Licentiate of Engineering Thesis, Lulea University of Technology, Lulea, Sweden (2009).

33. Surarak, C., Likitlersuang, S., Wanatowski, D., Balasubramaniam, A., Oh, E., and Guan, H. "Stiffness and strength parameters for hardening soil model of soft and stiff Bangkok clays", Soils and Foundations, 52(4), pp. 682-697 (2012).

34. Brinkgreve, R.B.J., Kumarswamy, S., and Swolfs, W.M., PLAXIS 2D Reference and Material Models Manuals, PLAXIS bv, the Netherlands (2016).

35. Lade, P.V., Yamamuro, J.A., and Bopp, P.A. "Significance of particle crushing in granular materials", $J$. Geotech. Eng., 122(4), pp. 309-316 (1996).

\section{Biographies}

Riaz Bhanbhro is an Assistant Professor at the Department of Civil Engineering, Quaid-e-Awam University of Engineering Science and Technology (QUEST). Nawabshah, Pakistan. He received his PhD from Luleå University of Technology (LTU), Sweden. His research interests are mainly in the testing and modeling of granular and fine-grained soils.

Roger Knutsson is a doctoral student at the Department of Civil, Environmental and Natural Resources Engineering, Luleå University of Technology, Sweden. His main research interests are mechanical properties of tailings and use of numerical modeling of commercial software for prediction of deformations and stability of tailings dams.

Muhammad Auchar Zardari is an Assistant Professor at the Department of Civil Engineering, QUEST, Nawanshah, Pakistan. He is currently involved in the numerical analysis of stability and deformations in embankment dams.

Tommy Edeskär is a Senior Lecturer at the Department of Civil, Environmental and Natural Resources Engineering, LTU, Sweden. Major research areas of his interest are earthfill dams, materials for construction purpose, and cold region engineering.

Sven Knutsson is a Professor at the Department of Civil, Environmental and Natural Resources Engineering, LTU, Sweden. His main research interests are frost, thaw weakening, permafrost, snow mechanics, water retention dams, internal erosion, stability of tailings dams, mechanical properties, long-term stability, and dredging and deposition of dredged sediments. 